\title{
BASIC CONCEPTS OF TAX SECURITY AS PART OF THE FINANCIAL SECURITY OF UKRAINE
}

\author{
Sergiy GOLIKOV', \\ Taras Shevchenko National University of Kyiv, Ukraine
}

\begin{abstract}
The purpose of the paper is to examine the essence of the term «tax security», its fundamental characteristics, such as threats, risks, interests and protection, defined how the state could provide them. The paper analyses economic, social and legal nature of the term. Key indicators of tax security of Ukraine identified and analyzed. In addition, the paper studies an integrated approach of tax security threats. In case of a big amount of threats, they divided to four main sources of threats: the state of the national economy, the state of the public finances, social features of the society and institutional environment. For each source, there have been identified and analyzed the most important factors of threats of tax security of Ukraine. Methodology. The survey based on an analysis of existing studies of Ukrainian and foreign scientists about the essence and nature of "tax security" for the last 10 years. In addition, to determine the essence and the concept, goals and objectives, methods and principles of the economic nature of the tax security, main risks, threats, expectations and results of efficient tax security identified. To build an integrated approach it is necessary to analyse all existing and potential factors of threats. There data used from reports of the State Statistics Service of Ukraine, Ministry of Economic Development and Trade of Ukraine, PWC and World Bank. Results of the survey showed that tax security is such a condition of tax security, when the process of harmonization of taxation provided under effective management of risks and threats that arise in tax area, by taking the necessary measures by the executive bodies to meet the interests of the state, society and taxpayers (business entities, organizations, people). Integrated approach of threats analysis of tax security shows that the most dangerous threats are those that are associated with poor economic development, considerable socio-economic stratification of the population, the level of shadow economy and low tax culture. The threat of the state of public finances is sufficiently large threat, but not the most dangerous, but the increase in the budget deficit and debt can affect significantly negatively on the tax security of Ukraine. The institutional environment is another threat to the tax security. Its main danger are the low efficiency of the tax authorities and uncertainty and ambiguity of legislation. Practical implications. In order to prevent a drop in tax security it is necessary to conduct continuous monitoring aforementioned factors on the sources of threats. All mentioned sources of threats would help the state authorities to build an effective Concept of Tax Security of Ukraine.
\end{abstract}

Key words: tax security, financial security, economic security, indicators of tax security, tax security criterias, taxation.

JEL Classification: F52, H2, H7

\section{Introduction}

Social and economic life of Ukraine depends on the security of all spheres of the state. Imbalances in the financial system of Ukraine connected with high risks and threats in the tax system. The main risk is a significant tax burden on economic entities, local budget deficit, low tax revenues, problems in the formation of the tax debt and so on. It is necessary to explore the essence of the concept of "tax security" and its main characteristics to resolve these problems. A considerable part of Ukrainian and foreign scientists engaged in research of transformation processes in the economy related to state tax policy. The study of the nature and basic characteristics of the security tax given a great interest, because the level of tax security shows the effectiveness of the tax system as a whole and it will help to analyse whether the amount of revenue meets the needs of the state, business and society in general. The main Ukrainian scientists on researching tax security are Baranovskiy, Berezhna, Belostotskiy, Ishchenko, Zadorozhniy, Martyniuk, Poljanska, Sokolovka, and among foreign authors - Arefiev, Kashin, Ponomariev, Timofeev and Tikhonov. However, despite considerable researches in tax security, still more attention should be paid to the research of its fundamental characteristics, threats, risks, and protect the interests.

Corresponding author:

${ }^{1}$ Department of Finance, Taras Shevchenko National University of Kyiv.

Email: sergiy.golikov@mail.ru 


\section{Economic, legal and social aspects of the term "tax security"}

After some investigation, the essence of "tax security" we can say that the scientists understand it as a form of security that must ensure the conditions of interaction between state, business entities and individuals in order to achieve the principle of mutual responsibility of management. The complexity of this term is that the authors define different features to this category (Ishchenko, 2012). Firstly, the tax security characterizes the security protecting of taxpayers interests and those who distribute gross domestic product through taxation. Second, the ability of the system is to perform its functions in time and to respond to any changes. Third, the ability and capacity to respond to the risks and hazards, eliminate, minimize, accept or ignore their impact on the tax security of all counter-parties. It is necessary to examine thoroughly this economic term, namely to analyse the economic, social and legal nature of its existence. This will allow characterizing the concept of "tax security", its characteristics and principles of its functioning.

The economic aspect of tax security means the level of fullness budget financial resources, which affects by a number of factors: the level of economic development, growth of gross domestic product, inflation, the tax burden on economic entities involved in reproduction. For better understanding of this aspect, you need to understand what does tax efficiency mean and how does it level determined.

Theoretically, the tax system should not prevent people to allocate their time and resources in a way that gave them the most benefit. Taxes that satisfy this condition, called neutral taxes - that taxes do not undermine the structure of consumer spending, manufacturing in firms, they do not push individuals and companies to avoid paying taxes and do not create unnecessary tax burden. A neutral tax is not pushing people to spend more of their resources on business trips, medical care, reduce the cost of food and clothing just because a business trip or medical services, for example, is not taxed, and clothes and foodstuffs are taxed. Taxes should not force people and businesses to spend more time and money in search of investment, which seems to reduce the tax burden.

The effectiveness of taxes can show by the ratio of costs and results. The results can considered as the amount of taxes collected by the state budget, expenditures - funds for levying these taxes. On the other hand, if the payer has paid a large sum of taxes, it may cause a decrease in the activity of entrepreneurs and investors or business may shift into shadow that subsequently leads to a reduction in tax revenue (Kashin, 2008).

The legal aspect means the control of the tax system, creating conditions for fair taxation of social reproduction and declarations in terms of laws. In addition, abuse in the distribution of the budget can be minimized through regulated provisions. However, it is difficult to avoid

Table 1

The main risks, threats, expectations and results for tax security

\begin{tabular}{|c|c|}
\hline Risks & Threats \\
\hline $\begin{array}{l}\text { For the state: } \\
\text { 1. The inability to obtain the planned volume of tax revenues; } \\
2 \text {. inability to perform their functions; } \\
\text { 3. The increase of the budget deficit due to a shortfall in tax } \\
\text { payments; } \\
\text { 4. The increase of tax offenses and abuses. } \\
\text { For taxpayers: } \\
\text { 1. Tax pressure increase; } \\
\text { 2. The complexity of the taxation; } \\
\text { 3. penalties for late payment of taxes, because of the complexity of } \\
\text { the tax system; } \\
\text { 4. The suspension of business. }\end{array}$ & $\begin{array}{l}\text { For the state: } \\
\text { 1. The tax evasion; } \\
\text { 2. The inefficient use of collected taxes; } \\
\text { 3. The increase in administration costs; } \\
\text { 4. The lack of tax culture; } \\
\text { 5. The constant changes in legislation.. } \\
\text { For taxpayers: } \\
\text { 1. Excessive supervision of regulatory bodies; } \\
\text { 2. Unfair amount of tax burden among the various levels of business } \\
\text { entities; } \\
\text { 3. The growth of the shadow economy; } \\
\text { 4. Capital flowing abroad. }\end{array}$ \\
\hline Opportunities & Results \\
\hline $\begin{array}{l}\text { For the state: } \\
\text { 1. Timely and full payment of taxes by the business entities; } \\
\text { 2. Creating conditions to encourage households; } \\
\text { 3. The existence of an effective tax system and tax sharing; } \\
\text { 4. Regulation of the tax collection mechanism and developing } \\
\text { effective methods of dealing with tax evasion. } \\
\text { For taxpayers: } \\
\text { 1. The ability to pay taxes on time and fully; } \\
\text { 2. Transparent and efficient allocation of collected budget funds; } \\
\text { 3. The increase of tax culture by business entities and consumers; } \\
\text { 4. Creating incentives for small business. }\end{array}$ & $\begin{array}{l}\text { For the state: } \\
\text { 1. Reduce management costs and taxes; } \\
\text { 2. Determine the optimal conditions of taxation of business entities; } \\
\text { 3. Develop an effective relationship between the amount of taxes and } \\
\text { the size of tax benefits; } \\
\text { 4. Prevent regular changes to the legislation. } \\
\text { For taxpayers: } \\
\text { 1. Transparency and clarity of tax reporting for business entities; } \\
\text { 2. Justice in resolving disputes and controversies between public } \\
\text { authorities and business entities; } \\
\text { 3. Simplification of tax control for business entities by reducing the } \\
\text { number of inspections and pressure; } \\
\text { 4. The opportunity to be informed about significant changes in } \\
\text { legislation (creating informational online resources) }\end{array}$ \\
\hline
\end{tabular}


abuses due to the political and economic crisis, and of the fact that there are some differences and difficulties in the Ukrainian legislation. The main difficulties are the contradiction of two types of accounting - financial and tax, many-sided interpretation of the distribution of the taxable costs and revenues, uncertainty in calculation of financial result, a single social contribution, income tax, value added tax and so on. As a result, all above-mentioned difficulties complicated process of declaring financial results of economic activity, there are ways to deliberate and so-called legal evasion of payment of certain taxes and reducing the total revenue of the state.

The social aspect is the level of protection of interests of all entities - government, business entities and the public, through a fair taxation, tax preferences, and tax sharing between the subjects of the financial system. So-called "tax culture" rules and discipline should established, which would provide the necessary level of tax security. Social orientation taxes must manifested by the ratio of direct and indirect taxation. Moreover, direct taxation should prevail, which will reduce the burden on the consumers themselves, and in case of effective tax rates will activate the production in the state. Moreover, collected taxes should be effectively implemented to solve socio-economic problems to satisfy the interests of both counter-parties: the state and the public.

Thus, only through sustainable development of economy, society and rational use of budgetary funds can achieve the necessary level of tax security that will satisfy the interests of all economic subjects. However, it is only possible with an effective, efficient and rational tax system (Ivanov, 2010).

\section{Risks, threats, expectations and results analysis for tax security of all subjects of tax security}

To determine the essence and concept, goals and objectives, methods and principles of the economic nature of tax security it is necessary to identify the main security risks, threats, expectations and results if it will work effectively. To avoid duality we should determine the parameters listed above both the state (subject, which charges taxes) and taxpayers (subjects, who pays those taxes). We should consider under the risk the probability of adverse events for tax security caused by the inefficiency of the tax system, the effect of threats that are already exist, and the external and internal factors impact on it.

The following table shows the main risks, threats, expectations and results for tax security (table 1). Tax security characterized by the ability to maintain subjects results of their work under the influence of a variety of both external and internal threats and risks. The main goal of the state is to minimize tax risks by reducing the number of situations that cause a threat to tax security for economic entities, society and the economy in general. On the other hand, businesses must consider the danger and threat of their activities and conduct economic activity only until in the ratio results- costs results exceeded. Otherwise they will be forced to stop their activities, will make certain changes improve the efficiency or will go into the shadows, which has a negative impact for the state, because entities are the largest source of tax payments (Voloshin, 2012).

To ensure a sufficiently high level of social and economic life, tax shortcomings should be considered, which caused inefficient and inadequate relation of the state to taxpayers, and creating destabilizing effects in the tax system, such as tax abuses and violations, many tax evasion and using of intricate charging schemes (Polonska, 2011). All tax risks should be carefully studied, analysed and measures to be undertaken to eliminate them. Thus, tax security should mean a tax system that allows harmonizing taxation processes, on condition of an effective management of tax risks and threats by the state's executive bodies, in order to satisfy the interests of economic entities.

\section{Basic indicators of tax security on different level}

Tax policy is one of the main instruments for building an effective and efficient tax system, whose main task is filling the budget with sufficient amount of taxes, effective use of them, creating the conditions for entry into the world finance community (Soloviev, 2011). It is always difficult to make the right decisions for the state; therefore, it is necessary to use of tax security indicators. The calculations of tax security indicators should use for further analysis and the data to use for forecasting key

\section{Table 2}

\section{The main indicators of tax security} by certain categories

\begin{tabular}{|c|l|}
\hline $\begin{array}{c}\text { Categories } \\
\text { of tax security }\end{array}$ & \multicolumn{1}{c|}{ Main indicators } \\
\hline International & $\begin{array}{l}\text { 1. The degree of harmonization of tax systems } \\
\text { of other countries; } \\
\text { 2. The sharpness and clarity of taxation to the } \\
\text { foreigner. }\end{array}$ \\
\hline State tax security & $\begin{array}{l}\text { 1. The level of shadow economy; } \\
\text { 2. The level of capital flows abroad; } \\
\text { 3. The level of tax culture; } \\
\text { 4. simplicity of tax control; } \\
\text { 5. the efficiency of collected budget funds; } \\
\text { 7. The stability of tax legislation; } \\
\text { 8. The level of taxpayers subsidies; } \\
\text { 9. The ratio of actual tax collection and } \\
\text { revenue from them; } \\
\text { 10. The level of tax efficiency; } \\
\text { 11. The level of trust to public authorities. }\end{array}$ \\
$\begin{array}{l}\text { 1. The level of the tax burden; } \\
\text { 2. The level of tax forecasting; } \\
\text { 3. The number of inspections per year; } \\
\text { 4. The effectiveness of tax management; } \\
\text { 5. clarity of legislation. }\end{array}$ \\
\hline
\end{tabular}


indicators of the tax system. Properly designed and timely calculated indicators make it possible to have on hand the actual figures on economic development. There is still no legal standards for determining indicators of tax security in Ukraine; therefore, we can take Calculation method of economic security, developed by the Ministry of economic development and trade of Ukraine. Indicators should split for certain subjects of tax system: international tax security, state tax security and private entity tax security. The following table shows the main indicators of tax security by certain categories (table 2 ).

This table shows the basic indicators of tax security, the main of which is the efficiency of the taxes, a legal part of taxation, level of shadow economy and tax culture. One of the leading indicators is the level of tax burden on taxpayers, which shows the impact of taxes and fees on a single entity and the economic situation of the state.

Tax security is closely linked to the level of tax culture, which manifests itself in compliance with all legal tax laws and other legal acts by businesses, timeliness and accuracy of paying taxes, knowledge of laws, own rights and obligations, trust to the government and in its effective redistribution of all collected taxes and duties (Korobov, 2010).

Trust and mutual cooperation between all subjects of tax relations will develop tax culture, which is the basis of fundamental changes in the tax policy of the state, building an effective national economy and ensuring reliable security of tax Ukraine. However, despite the implementation of reforms in the tax system, the state of the tax security is still unstable because of the effect of certain risks, including: unsustainable economic growth and excessively high sensitivity to external factors; big number of shortcomings in the tax system, inefficient tax administration and lack of control in use of budget funds; high level of shadow economy (47\% of shadow economy in 2015); monopoly ownership over strategic enterprises in strategic sectors of the economy by foreign companies; low efficiency of defending the national market from unfair competition of foreign products; lack of scientific and technological progress and sufficient investment in the economy.

\section{Integrated approach of threats analysis of tax security}

In order to clarify the content of threats of tax security for the state we should apply an integrated approach, which identify the existing and potential sources and factors of threats. Sources of threats as possible causes of threats can cause destructive factors that adversely affecting the level of tax security and lead to threats. There are a significant number of factors of threats and other negative circumstances which negatively affect the efficiency and stability of tax security. Existing destabilizing factors grouped by source of origin.

The main sources of threats are the state of the national economy, state of the public finances, social features of the society and institutional environment. A number of factors allocated for each of the above sources of threats, the impact of which is the most critical and can cause a harmful impact. In addition, the vulnerability of certain areas of the tax system should take into account.

The most significant effects of tax security should include the nature of economic development, social welfare and the degree of inflation. The nature of economic development means that economic growth in the state economy has the ability to reduce certain servicing costs the economy at the same time reducing the need for tax revenue. The nature of economic development means that the state economy has the ability to reduce certain servicing costs for the economy during an economic growth and reduce the need for tax revenues at the same time. However, despite the decrease in servicing costs on the economy, tax revenues may grow. This explains by the fact that during the boom phase in the growth of the economy, income of the individuals and entities increase, and household consumption increase, which in turn increases income taxes.

The most important indicators of the national economy is the level and dynamics of GDP. In the following table is given the numerical value of these indicators (table 3 ).

Table 3

The growth rate of nominal GDP of Ukraine over the period 2009-2014

\begin{tabular}{|c|c|c|c|}
\hline Year & $\begin{array}{c}\text { Nominal GDP, } \\
\text { mln. UAH. }\end{array}$ & $\begin{array}{c}\text { Absolute growth } \\
\text { of nominal GDP, } \\
\text { mln. UAH. }\end{array}$ & $\begin{array}{c}\text { The growth } \\
\text { rate of nominal } \\
\text { GDP,\% }\end{array}$ \\
\hline 2008 & 948056 & 227325 & 31,5 \\
\hline 2009 & 913345 & -34711 & $-3,7$ \\
\hline 2010 & 1082569 & 169224 & 18,5 \\
\hline 2011 & 1316600 & 234031 & 21,6 \\
\hline 2012 & 1408889 & 92289 & 7,0 \\
\hline 2013 & 1454931 & 46042 & 3,3 \\
\hline 2014 & 1566728 & 111797 & 7,7 \\
\hline
\end{tabular}

According to the table we can observe a decrease in nominal GDP in 2009 to $34711 \mathrm{mln}$. UAH, which can be explained by the downturn in the economy as a result of the global financial crisis, which caused a significant negative impact on the economy of Ukraine. GDP growth in 2010-2014 years has been unable to reach its pre-crisis value. The dynamics remain positive, but the pace of growth slowed considerably - GDP growth in 2013 was only $3.3 \%$. This can explained by the decline in production for most types of economic activity that began in 2011 and continues up today. Such dynamics of GDP creates big risks to macro environment of the state and can cause even greater need for additional tax revenues to the state's budget.

The welfare level. At a high level of welfare, there is a potential basis for an increase in tax revenues in case of urgency, when the state needs for additional funds. When there is low level of prosperity, any attempts at extra cash from tax revenues will be ineffective. In addition, such 
actions affect adversely on the level of tax security. To demonstrate this factor look at the dynamics of the value of GDP per capita. According to The Global Competitiveness Report World Economic Forum, the GDP in Ukraine in 2013 was $\$ 3,919.41$. Despite the rather low level of GDP growth, Ukraine is on the 91 place out of 144 countries in terms of GDP per capita. The closest our neighbours are Lithuania ranks 44th (\$16,003.00), Russia - 49th place $(\$ 14,819.00)$, Poland - 52 place $(\$ 13,394.00)$, Kazakhstan - 53 place $(\$ 12,843.00)$, Romania - 67th $(\$ 8,910.00)$. Thus, welfare remains very low even in comparison with countries of the former USSR Ukrainian. This poses a serious threat to the security tax, exacerbated by unfavourable GDP.

Inflation is the factor that has a significant impact on the level of tax security. Business entities often do not meet the legislative deadlines of tax collection under the conditions of high inflation, because sometimes potential fines and penalties from delayed payment of taxes is more profitable, as money constantly depreciating, and one monetary unit used today is more than one money unit used after a certain period of time. These actions significantly worsen the level of tax security and are a huge threat.

The second source of threats is the state of the public finances. The level and nature of the state's impact on the economy depends on the efficiency and functioning. The most important factors that affect the state of public finances is the size of the budget deficit, public debt and tax burden. The budget deficit under Article 2 of the Budget Code of Ukraine is the excess of expenditures over gainful. The following table shows the values of the state budget deficit in recent years (table 4).

Table 4

The volume of the budget deficit in Ukraine over the period 2009-2014

\begin{tabular}{|c|c|c|c|c|}
\hline \multirow[b]{2}{*}{ Year } & \multicolumn{3}{|c|}{ State Budget (mln. UAH) } & \multirow{2}{*}{$\begin{array}{c}\text { State's ratio of } \\
\text { budget deficit/ } \\
\text { surplus to GDP,\% }\end{array}$} \\
\hline & Revenues & Expenditures & $\begin{array}{l}\text { Deficit/ } \\
\text { surplus }\end{array}$ & \\
\hline 2008 & 231686,3 & 241454,5 & $-12500,7$ & $-1,32$ \\
\hline 2009 & 209700,3 & 242437,2 & $-32736,9$ & $-3,89$ \\
\hline 2010 & 240615,2 & 303588,7 & $-62973,5$ & $-5,94$ \\
\hline 2011 & 314616,9 & 333459,5 & $-18842,6$ & 1,79 \\
\hline 2012 & 346025,5 & 395681,5 & $-49656,0$ & $-3,79$ \\
\hline 2013 & 339180,3 & 403403,2 & $-64707,6$ & $-4,45$ \\
\hline 2014 & 403403,2 & 430108,8 & $-78070,5$ & $-4,98$ \\
\hline
\end{tabular}

According to the data presented above table shows that in Ukraine there is a constant budget deficit during the study period. Great value of the budget deficit in 2010 is explained by the global financial crisis, which led to increase the costs for anti-crisis measures. Ratio deficit/ surplus to GDP should not exceed 3\%. The state budget deficit was within the allowable ratio only in 2008 and 2011. It is exceeding the rate of the marginal rate of $3 \%$ in 2009-2011 and 2012-2014, and the value continues to rise slowly. This is an evidence of a threatening situation for the whole system of public finance, including tax security. It may happen that the state will not have enough internal or external loans to cover the budget deficit, so the state will be forced to increase the tax rates, which can undermine the level of tax security.

Public debt under Article 2 of the Budget Code of Ukraine is the total debt of the state, both domestic and foreign, including all issued and outstanding debt obligations previously issued guarantees for loans etc. (Budget Code of Ukraine, 2010). Large public debt is a significant threat to the tax security of the state, as required large sums to its service - payments of interest or the body. Chart shows the size of the domestic and external debt, which is growing steadily (fig. 1). The national debt has increased by 516 billion. UAH. ( $88 \%$ ) by 2014 and reached 1.1 trillion. UAH. The reason was the growth in both domestic debts by $72 \%$, which reached 489 billion. UAH and the external debt by $103 \%$, that reached 612 billion. UAH. Thus, debt load reached a critical level (the level of debt in 2015 will increase to $94.1 \%$ of GDP). Such a high debt load explained by the fiscal and debt problems in public finances because of significant reduction in state revenues, increase of defence spending and expenditures, that will be used to service the public debt.

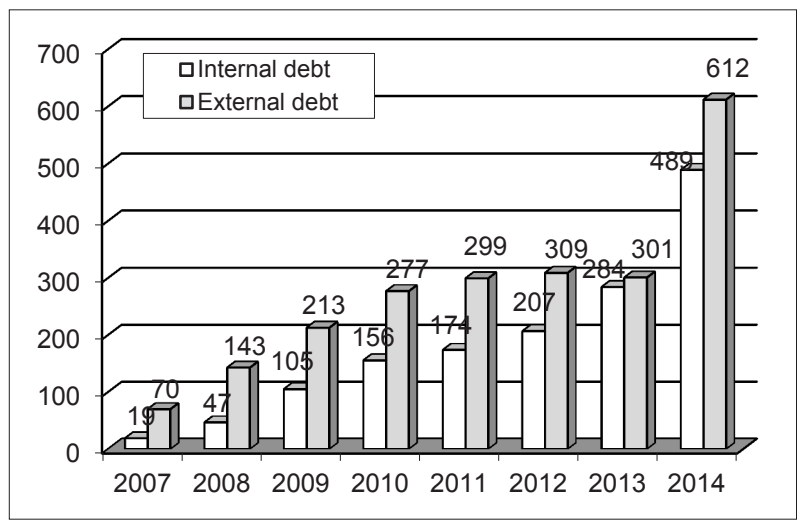

Fig. 1. The size of the internal and external public debt of Ukraine for 2007-2014, Bn. UAH

An important indicator of tax security is the ratio of public debt to GDP. The critical size of the rate must not exceed $60 \%$, according to the Budget Code of Ukraine. In recent years, the national debt built up rapidly, thereby worsening the debt security. The biggest debt burden is expected in 2015 for all the years of independence. The ratio of debt to GDP from 2001 to 2014 increased from 40 to $72.2 \%$ according to the information of the Ministry of Finance of Ukraine. This ratio could be $94.1 \%$ in 2015, according to the IMF. As a result, an increase in the cost of servicing the public debt expected, which reduces the possibility of government funding of other programs.

The problem of the tax burden is also very sharp issue because the tax burden is one of the main characteristics of the tax system of the state. According to statistics, the share of tax revenues to GDP in Ukraine in 2014 amounts $19.5 \%$. Compared to neighboring countries, the level of tax 
burden is in Belarus - $16 \%$, Poland - 17\%, Russia - 15\%, Bulgaria $-18.1 \%$. However, the level of tax burden is quite high in developed countries: Germany - 26.5\%, Sweden $22 \%$, Portugal - 23\%, Denmark - 35\%. However, all these countries solve successfully the problems of socioeconomic development, despite the high tax burden. Thus, Ukraine has a significant level of tax burden. Increasing tax burden in the future by introducing new taxes, may create unfavourable conditions for socio-economic development, tax revenues may fall and cause more menacing consequences for the tax security.

The third source of threats is an institutional environment, which carries also a huge threat to the security of the tax Ukraine. Main factors of threat are the level of the shadow economy, the culture of taxpayers, effectiveness of tax authorities and the stability of the legislation.

The level of the shadow economy is a very dangerous threat to the security tax, which is peculiar to all economies. However, countries with transitional economies are the most vulnerable to it. The shadow economy of Ukraine ranges from 38\% in 2010 to $47 \%$ in 2015 (Ministry of Economic Development and Trade, 2016). Almost half of Ukraine's economy is in the shadow, which causes a significant shortfall in taxes. Moreover, there are a layer of companies that "work in the shadows" and do not pay taxes to the budget, which distorts the distribution of the tax burden and it falls on honest taxpayers. As a result, the tax morality of law-abiding taxpayers decreases. Therefore large scale of shadow economy is a significant threat to the tax security of Ukraine.

The tax culture is low, which negatively reflects on the tax security of the state. The main reasons for the low tax culture and morality among taxpayers is insufficient awareness of the importance of tax revenues in social and economic development, high level of corruption in tax administrations, awareness of inefficient use of funds from the government budget, the examples of impunity for certain individuals or companies for tax violations, abuse of tax benefits, permanent changes in tax legislation.

The level of tax security largely depends on the efficiency of the tax authorities. Considerable dissatisfaction of tax authorities is observes recently, especially huge corruption, inefficient tax administration and control over tax payments. There has been some improvement in recent years, according to the report of $\mathrm{PwC}$ and the World Bank Group. They determine the ratio of ease of paying taxes. The overall time is 350 hours in 2015, that is necessary for the company to fulfil all tax obligations to the state, which is better by $28.7 \%$ than it was in 2013 (491 hours). However, this ratio is much higher than in many other countries. For example, in Estonia it amounted 81 hours, in Russian Federation - 168, in Lithuania - 175, in Belarus - 183 hours, Moldova - 185, Latvia - 193, Poland - 286 (Paying Taxes 2010, 2015. The Global Picture). We can observe more than double reduction in time needed to comply with tax obligations over the last 5 years. Improvement of this indicator became possible mainly due to optimization of tax payments and the introduction of electronic reporting and payment of taxes. Electronic reporting reduces administration costs, reduces direct communication between tax manager and taxpayers, and eliminates the possibility of corruption schemes.

Legislation stability is another factor of tax security threat. Constant changes in tax legislation occur during the years of independence of Ukraine. All political parties after coming to power are trying to lobby their own interests, as manifested in the adoption of changes to tax legislation. Thus, taxpayers are able to evade all their profits without paying the full tax payments to the budget and do not bear responsibility for it, due to constant changes in legislation, contradictions and ambiguities in its interpretation. In addition, inadequate legislation increases the risk of inefficient tax collection and monitoring of timely and in full payment of taxes.

Social threats of tax security are a significant socioeconomic stratification of the population. This problem has existed in Ukraine for many centuries. The tax burden distributed unevenly due to a flawed legislation. It is necessary to introduce a system of progressive taxation revenues in order to achieve fairness in taxation. However, it may still worsen security tax, because wealthy part of the Ukrainian society will try to find taxation that is more attractive. This may be investing in foreign countries, transfer of capital to offshore or other more favourable method of multiplying wealth.

\section{Conclusions}

Forming effective tax policies by selecting a winner model of tax payments can strengthen security tax. It is necessary to comply with the requirements tax security to the compliance requirements of national security to ensure effective economic development of Ukraine. Ukrainian government should regularly examine the effectiveness of methods, techniques and tools to ensure tax security. In addition, there is a need for the development and approval of the Concept of Ukraine's Security tax, which include main priorities, goals and objectives by providing tax security. There will be difficult to implement effective social and economic development of the state without the Concept.

Integrated approach of threats analysis of tax security shows that the most dangerous threats are those that are associated with poor economic development, considerable socio-economic stratification of the population, the level of shadow economy and low tax culture. The threat of the state of public finances is sufficiently large threat, but not the most dangerous, but the increase in the budget deficit and debt can affect significantly negatively on the tax security of Ukraine. The institutional environment is another threat to the tax security. Its main danger is low efficiency of the tax authorities and uncertainty and ambiguity of legislation. It is obligatory to conduct continuous monitoring of the above sources and factors of threats, which allow preventing a drop in tax security. 


\section{References}

Ischenko, V. (2012). The tax component of the financial security of the State, Visnyk ekonomiky transportu i promyslovosti, Kyiv, Ukraine.

Ivanov, I. (2010). Tax Security: the nature and terms of security, Ekonomika rozvytku, Kyiv, Ukraine.

Kashin, V. (2008). Tax system: how to make it more effective? Finansy, Moscow, Russia.

Korobov, V. (2010). Financial security in the system of state financial control: avtoref. dys. candidate. ek. science, Moscow, Russia.

Official web site of the Ministry of Economic Development and Trade. http://www.minfin.gov.ua/

Paying Taxes 2010. The Global Picture. - PWC and World Bank. (2010) https://www.pwc.com/gx/en/payingtaxes/assets/paying-taxes-2010.pdf

Paying Taxes 2015. The Global Picture. - PWC and World Bank. (2015) https://www.pwc.com/gx/en/payingtaxes/pdf/pwc-paying-taxes-2015-low-resolution.pdf

Polonska Y.M. (2011). Organizational support of system management decisions in tax planning criterion for tax security, Kyiv, Ukraine.

Soloviev, V. (2011). Financial security as a fundamental factor of the state's independence, Bulletin Berdyansk University of Management and Business, Berdyansk, Ukraine.

Voloshin, V., Karkavchuk, V. (2012). System approach to analysis and ensure financial security of the company, Donetsk, Ukraine.

\section{Сергей ГОЛИКОВ}

\section{ОСНОВНЫЕ ПРИНЦИПЫ НАЛОГОВОЙ БЕЗОПАСНОСТИ КАК СОСТАВЛЯЮЩЕЙ ФИНАН- СОВОЙ БЕЗОПАСНОСТИ УКРАИНЫ}

Аннотация. Целью работы является изучение сущности термина «налоговой безопасности», его основных характеристик, таких как угрозы, риски, интересы и способы защиты, определить, каким образом государство может предоставить их. В статье проанализирован экономический, социальный и правовой характер этого термина. Выявлены и проанализированы основные показатели налоговой безопасности Украины. Кроме того, в статье рассматривается комплексный подход анализа угроз налоговой безопасности. Из-за большого количества угроз, они разделены по четырем основным источникам угроз: состояние национальной экономики, состояние государственных финансов, социальные особенности общества и институциональной среде. Для каждого источника, были выявлены и проанализированы наиболее важные факторы угроз налоговой безопасности Украины. Методология. Исследование основано на анализе существующих исследований украинских и зарубежных ученых о сущности и характере «налоговой безопасности» за последние 10 лет. Кроме того, чтобы определить сущность и понятие, цели и задачи, методы и принципы экономического характера налоговой безопасности, были определены основные риски, угрозы, ожидания и результаты эффективной налоговой безопасности. Для построения комплексного подхода необходимо проанализировать все существующие и потенциальные факторы угроз. Данные взяты из отчетов Государственной службы статистики Украины, Министерства экономического развития и торговли Украины, РWC и Всемирного банка. Результаты исследования показали, что налоговая безопасность является таким состоянием налоговой безопасности, когда процесс гармонизации налогообложения взаимодействует с эффективным управлением рисками и угрозами, которые возникают в налоговой сфере, путем принятия необходимых мер исполнительными органами для удовлетворения интересов государства, общества и налогоплательщиков (хозяйствующих субъектов, организаций и людей). Комплексный подход анализа угроз налоговой безопасности показывает, что наиболее опасными угрозами являются те, которые связаны с плохим экономическим развитием, значительным социально-экономическим расслоением населения, уровнем теневой экономики и низкой налоговой культурой. Угроза состояния государственных финансов является достаточно важной, но не самой опасный, но все же увеличение бюджетного дефицита и долга может существенно негативно сказаться на налоговой безопасности Украины. Институциональная среда является еще одной угрозой для налоговой безопасности. Её главной опасностью являются низкая эффективность налоговых органов, неопределенность и неоднозначность законодательства. Практическое значение. Для того, чтобы предотвратить снижение налоговой безопасности необходимо проводить непрерывный мониторинг указанных выше факторов на источники угроз. Все упомянутые источники угроз бы помочь органам государственной власти выстроить эффективную Концепция налоговой безопасности Украины. 